\title{
Prediction of Foaming Process in the Production of Aluminium Foams
}

Iva Nová ${ }^{1}$, Jiř́ Sobotka ${ }^{1}$, Karel Fraňa ${ }^{2}$, Pavel Solfronk ${ }^{1}$, David Koreček ${ }^{1}$, Iva Nováková ${ }^{1}$,

${ }^{1}$ Technical University of Liberec, Faculty of Mechanical Engineering, Department Engineering Technology; ${ }^{2}$ Technical University of Liberec, Faculty of Mechanical Engineering, Department of Energy Facilities. Studentská 1402/2, Czech Republic. E-mail: iva.nova@tul.cz, karel.frana@tul.cz, jiri.sobotka@tul.cz., pavel.solfronk@tul.cz, david.korecek@tul.cz,iva.novakova@tul.cz.

The paper deals with the physical-chemical effects of a blowing agent on production the cellular metal systems (in this case aluminium foams). Based on the isothermal concertation and pressure curves for the $\mathrm{H}$-Ti system and by using the maximum gas volume obtained from equation of state, there was applied the blowing agent to $1 \mathrm{~kg}$ of AISi12 aluminium alloy. Moreover, using relation to determine aluminium foam relative density ( $\rho$ REL) from alloy AISi12, there was done prediction to determine density of $1 \mathrm{~kg}$ metal foam from AlSi12 alloy at different blowing agent contents from 0.1 up to $1.5 \mathrm{wt} \%$ of titanium hydride $\mathrm{TiH}_{2}$. These isothermal calculations were compared with the density of aluminium foal from alloy AISi12, which was produced by an industrial process. Basic mechanical properties were subsequently measured on the produced foam samples.

Keywords: Aluminium foam, aluminium alloy, foaming process, volume, foam density.

\section{Introduction}

As it is known by ASHBY [1], BANHAR [2, 3], RAJAK [4] and many other researchers e.g. [5, 6, 7], the production of cellular metals (foam metals) is possible to be divided into five groups, but three groups are the most widely used in industry. One group is based on direct gas flow into the melt with gas from an external source (argon, nitrogen, air), the second group is based on a powder foaming agent that is added to the melt and the third group is based on a powder foaming agent that is mixed with the metal powder. At production metal foams, it is always and in all cases necessary to add such substances that improve properties of relevant metal with respect to the foaming process (e.g. $\mathrm{SiC}, \mathrm{Al}_{2} \mathrm{O}_{3}$, etc.). The utilization of foaming agents is quite attractive, because it is relatively inexpensive. On the other hand, the whole process of producing foam metals (especially aluminium and its alloys) is very demanding. This difficulty is associated with high oxygen affinity to aluminium. Although the foaming process is controlled, resulting foam structure formation depends on the melt properties and processing conditions. Generally, compared to other foaming mediums (e.g. detergents), the knowledge about the basic mechanisms of foaming processes for metals is still relatively inadequate. It is very true also for the process of producing aluminium foams, where the foaming agent is added to the melt or powder metallurgy process is used. In this case are powders of metal, stabilizing agent and the foaming agent $\left(\mathrm{TiH}_{2}\right)$ mixed and cold formed densified and then are foamed in a shape mould. The hydrogen released from the foaming agent dissolves in liquid aluminium and diffuses into the nucleus of gas bubble. THIES [5] dealt with the relevant physical-chemical process and the mechanism of the foaming process based on the powder foaming agents and concluded that behaviour of the foaming agent can be divided into five stages: decomposition, nucleation, solubility and diffusion, bubble formation and bubbles behaviour in the metal melt. SIMONS et al. [9] investigated the formation of bubbles in incompressible viscous Newtonian fluid and simulation of its formation.
MATIJASEVIC et al. [10] performed pre-treatment of $\mathrm{TiH}_{2}$ for the foaming process. These properties were scanned by the analysis using TGA, DSC and MS. The conclusions of their research were applied in the production of aluminium foams from AlSi6Cu4 alloy and there was assessed the quality of gasification.

\section{Metal foaming process with utilization of foaming agent}

Many researchers, such as e.g. KRESSE [7] and YANG [8], have been concerned with the production of metal foams by means of foaming agents. KRESSE [7] monitored the foaming process based on the thermal decomposition of $\mathrm{TiH}_{2}$. The decomposition of titanium hydride $\left(\mathrm{TiH}_{2}\right)$ is evident from the phase diagram or diagram of the concentration and pressure isothermal curves of the $\mathrm{H}-\mathrm{Ti}$ system, according to San-Martin and Manchester [10]. However, it is important to note that the phase diagram is valid just for the equilibrium system of the titanium hydride. The presence of an aluminium matrix and other stabilizing agents $\left(\mathrm{SiC}, \mathrm{Ca}, \mathrm{Al}_{2} \mathrm{O}_{3}\right)$ to maintain foam stability can cause more complex reactions. The formation of intermetallic phases $\mathrm{Ti}-\mathrm{Al}$ and titanium oxidation is also likely. All these circumstances affect (promote or prevent) the thermal decomposition of $\mathrm{TiH}_{2}$ as is written in ZEPPELIN [11].

At the same time KRESSE [7] dealt with the foaming agent expansion as a function of temperature. He concluded that effect of foaming agent $\mathrm{TiH} 2$ for the gasification process can be divided into five stages (designated 0 to IV). Stage 0 - thermal expansion of metal; stage I - nucleation of gas bubbles in the solid metal; Stage II - expansion of bubbles in the semi-solid region of the metal; Stage III - expansion of melt bubbles within its temperature range; Stage IV - collapse of foam. In addition to the expansion curve, Fig. 1 shows also the $\mathrm{TiH}_{2}$ hydrogen release curve [7]. For the production of aluminium foam, the start of the foaming process (stage 0 to II in Fig. 1), is characterized by the decomposition of foaming agent and nucleation of bubbles in aluminium. Decomposition of 
about 0.5 wt. $\% \mathrm{TiH}_{2}$ up to $700^{\circ} \mathrm{C}$ releases approximately a gas volume that $10 x$ exceeds the precursor volume. Decomposition begins at temperature of about $450^{\circ} \mathrm{C}$ (aluminium is still in solid state). At production of metal foams, resp. aluminium foams, beside the titanium hydride $\left(\mathrm{TiH}_{2}\right)$ as major foaming agent, the application of other hydrides (e.g. $\mathrm{ZrH}_{2}, \mathrm{MgH}_{2}, \mathrm{CaH}_{2}$ ) or carbonates $\left(\mathrm{MgCO}_{3}, \mathrm{CaCO}_{3}\right)$ may be considered in some cases. But the most common one is $\mathrm{TiH}_{2}$. Titanium hydride provides a large amount of hydrogen, i.e. $9.2 \cdot 10^{22}\left[\right.$ atoms $\left.\cdot \mathrm{cm}^{-3}\right]$. In light of its amount, $\mathrm{TiH}_{2}$ is used from 0.5 to $1.5 \mathrm{wt} . \%$.

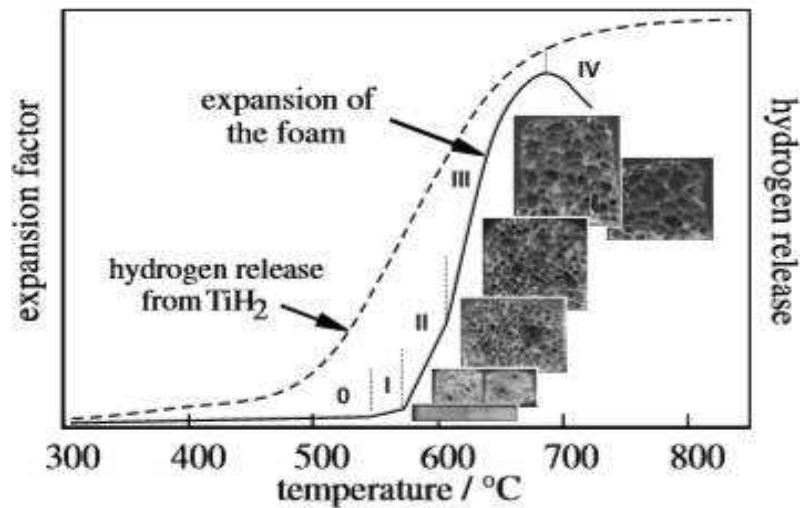

Fig. 1 Curves of releasing hydrogen vs. temperature from $\mathrm{TiH}_{2}$ (left); course of the foam temperature expansion in dependence on temperature (right) can be di-

vided into five modes: 0 ) thermal expansion of the metal; I) nucleation of bubbles in solid metal; II) expansion of bubbles in the semi-solid metal; III) expansion of bubbles within the temperature range of the melt; IV) collapse of foam [7]

\section{Theoretical calculations for the titanium hy- dride foaming process application at AISi12 alloy foam production}

In our research, calculations were made to determine foam density based upon the theoretical calculations of foaming agent volumes, using a certain amount of $\mathrm{TiH}_{2}$ (expressed in wt\%: e.g. $1 \mathrm{wt} \%=10 \mathrm{~g}$ ) per $1000 \mathrm{~g}$ of metal. It is possible to determine the volume of gas regarding the equation of state (1). After that, there can be predicted foaming of $1 \mathrm{~kg}$ AlSi12.

$$
p \cdot V=n \cdot R \cdot T,
$$

Where: $\mathrm{V}$ is volume $\left[\mathrm{m}^{3}\right] ; \mathrm{n}$ is amount of substance [mol], $\mathrm{R}$ is universal gas constant $\left[\mathrm{J} \cdot \mathrm{mol}^{-1} \cdot \mathrm{K}^{-1}\right]$, $\mathrm{T}$ is absolute temperature $[\mathrm{K}]$ and $\mathrm{p}$ is pressure of gas $[\mathrm{Pa}]$.

The gas volume determination is calculated according to equation (1):

$$
V=n \cdot \frac{R \cdot T}{p}=\frac{m}{M} \cdot \frac{R \cdot T}{p}
$$

Where: $\mathrm{m}$ is weigh [g], (in this case for $1 \mathrm{wt} . \% \mathrm{TiH}_{2}$ is $\mathrm{m}=10 \mathrm{~g}$ ); $\mathrm{M}$ is molecular weight $\left[\mathrm{g} \cdot \mathrm{mol}^{-1}\right]$ of $\mathrm{TiH}_{2} ; \mathrm{p}$ is $101325[\mathrm{~Pa}]$; $\mathrm{R}$ is $8.314 \mathrm{~J} \cdot \mathrm{mol}^{-1} \cdot \mathrm{K}^{-1}$; $\mathrm{T}$ is temperature [K].

In equation (2), the melting temperature of AlSi12 is taken as $577^{\circ} \mathrm{C}(850 \mathrm{~K})$ and molecular weight of $\mathrm{TiH}_{2}$ is $\mathrm{M}_{\mathrm{TiH} 2}=49.91 \mathrm{~g} \cdot \mathrm{mol}^{-1}(\mathrm{Ti}+2 \mathrm{H}=47.90+2 \cdot 1.008)$. Simultaneously, the relative density of foamed AlSi12 alloy can be calculated acc. to equation (3):

$$
\rho_{\mathrm{REL}}=\frac{\mathrm{V}_{\mathrm{BM}}}{\mathrm{V}+\mathrm{V}_{\mathrm{BM}}}
$$

Where: $\mathrm{V}_{\mathrm{BM}}$ is volume of basic material $\left[\mathrm{m}^{3}\right]$ and $\mathrm{V}$ is released gas volume from $\mathrm{TiH}_{2}\left[\mathrm{~m}^{3}\right]$.

Volume of basic material (non-foamed), resp. AlSi12 $\left(\mathrm{V}_{\mathrm{BM}}\right)$ is determined from the mass $\mathrm{m}=1 \mathrm{~kg}$ of AlSi12 and its density $\rho=2660 \mathrm{~kg} \cdot \mathrm{m}^{-3}$ according to relation (4):

$$
\mathrm{V}_{\mathrm{BM}}=\frac{1}{2660}=3.76 \cdot 10^{-4}\left[\mathrm{~m}^{3}\right]
$$

The density of foamed AlSi12 alloy is determined by the equation (5):

$$
\rho_{\mathrm{Al} \_\mathrm{F}}=\rho_{\mathrm{REL}} \cdot \rho_{\mathrm{BM}}
$$

\begin{tabular}{|c|c|c|c|c|c|c|c|}
\hline Foaming Agent & Foam Metal & $\begin{array}{l}\text { Content } \\
\text { of foaming } \\
\text { agent } \\
\text { [wt } \%]\end{array}$ & $\begin{array}{c}\text { Volume of } \\
\text { gas V } \\
{\left[\mathrm{m}^{3}\right]}\end{array}$ & $\begin{array}{c}\text { Volume of } \\
\text { basic metal } \\
\mathrm{V}_{\mathrm{BM}}\left[\mathrm{m}^{3}\right]\end{array}$ & $\begin{array}{c}\text { Relative } \\
\text { density } \\
\rho_{\text {REL }}[1]\end{array}$ & $\begin{array}{c}\text { Density } \\
\rho_{\mathrm{Al} \_\mathrm{F}} \\
{\left[\mathrm{g} \cdot \mathrm{cm}^{-3}\right]}\end{array}$ & $\begin{array}{c}\text { Density } \\
\rho_{\mathrm{Al} \_\mathrm{F}} \\
{\left[\mathrm{kg} \cdot \mathrm{m}^{-3}\right]}\end{array}$ \\
\hline \multirow{15}{*}{$\begin{array}{l}\text { Titanium hy- } \\
\text { dride }\left(\mathrm{TiH}_{2}\right)\end{array}$} & \multirow{14}{*}{ AlSi12 } & 0.10 & 0.0014 & \multirow{14}{*}{$3.76 \cdot 10^{-4}$} & 0.2120 & 0.564 & 564 \\
\hline & & 0.20 & 0.0028 & & 0.1184 & 0.314 & 314 \\
\hline & & 0.30 & 0.0042 & & 0.0822 & 0.219 & 219 \\
\hline & & 0.40 & 0.0056 & & 0.0629 & 0.167 & 167 \\
\hline & & 0.50 & 0.0070 & & 0.0510 & 0.135 & 135 \\
\hline & & 0.60 & 0.0084 & & 0.0428 & 0.113 & 113 \\
\hline & & 0.70 & 0.0098 & & 0.0368 & 0.098 & 98 \\
\hline & & 0.80 & 0.0112 & & 0.0325 & 0.086 & 86 \\
\hline & & 0.90 & 0.0126 & & 0.0289 & 0.077 & 77 \\
\hline & & 1.00 & 0.0140 & & 0.0261 & 0.070 & 70 \\
\hline & & 1.10 & 0.0154 & & 0.0238 & 0.063 & 63 \\
\hline & & 1.20 & 0.0168 & & 0.0219 & 0.058 & 58 \\
\hline & & 1.30 & 0.0182 & & 0.0202 & 0,054 & 54 \\
\hline & & 1.40 & 0.0196 & & 0.0188 & 0.050 & 50 \\
\hline & & 1.50 & 0.0210 & & 0.0176 & 0.047 & 47 \\
\hline
\end{tabular}

Where: $\rho_{\text {Al_F }}$ is density of foamed AlSi12 alloy $[\mathrm{kg} \cdot \mathrm{m}$ ${ }^{3}$ ]; $\rho_{\mathrm{REL}}$ is relative density of foamed AlSi12 alloy [1] and $\rho_{\mathrm{BM}}$ is density of basic material $\left[\mathrm{kg} \cdot \mathrm{m}^{-3}\right]$..

Tab. 1 Theoretical calculations of the foaming agent (titanium hydride) in $1 \mathrm{~kg}$ of aluminium alloy AlSil2 
These calculations were performed with application of equations (1) to (5), see in $\boldsymbol{T a b}$. $\mathbf{1}$, mentioned above, where the behaviour of $\mathrm{TiH}_{2}$ foaming agent for production aluminium foams was analysed. Based upon these calculations, the properties of aluminium alloy foams can be assessed

\section{Characteristic of production the AISi12 alloy foam samples}

Samples from AlSi12 foam were produced by the powder metallurgy at company LKR - Leichmetall Kompenzzentrum Ranshofen (Austria), how it is described in more detail in [12]. At this production, the AlSi12 alloy powder is mixed with the foaming agent powder $\left(\mathrm{TiH}_{2}\right)$ so that the mixture is as homogeneous as possible. From such prepared cold-formed mixture and subsequent hot extrusion (in solid state), a foam workpiece in the form of bars, wires or various open profiles is produced. This workpiece has within its whole volume uniformly dispersed and gas-tight foam particles. After that, workpieces were load into a foaming steel mould and heated above the aluminium melting temperature (AlSi12 aluminium alloy). This is followed by the melting of the workpieces and thermal decomposition of the $\mathrm{TiH}_{2}$. Melt from the aluminium alloy foam fills the cavity of the mould and copies its shape. After complete filling of the molten alloy with AlSi12 in the cavity of the foaming mould by hydrogen, there may indicate intentionally formed mould untightnesses. As a next phase, there is rapid cooling of the foamed steel mould below the melting point of aluminium or aluminium alloy. Due to that, foam from aluminium alloy with continuous surface layer (crust) and an internal porous structure is created. AlSi12 aluminium powder was used for the production of testing foam castings and as a foaming agent there was titanium hydride $\left(\mathrm{TiH}_{2}\right)$. In this way, $150 \times 25 \times 10 \mathrm{~mm}$ foamed samples were produced (see Fig. 2). In the Fig. 3 is chemical microanalysis of EDX foam sample aluminium AlSi12 alloy. All the technological principles that were also mentioned by KRESSE [7] were followed in order to produce foamed parts that is highly complicated in light of their production.

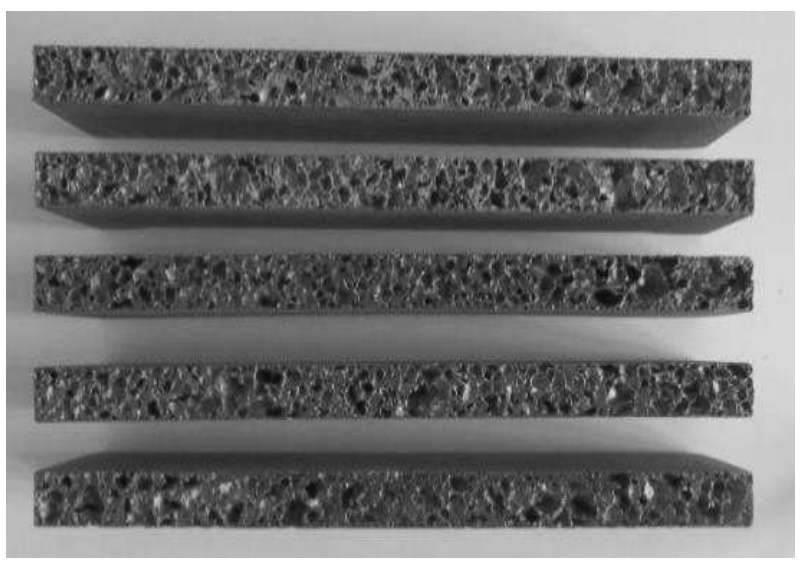

Fig. 2 Produced foamed parts $(150 \times 25 \times 10 \mathrm{~mm})$ from AlSi12 cast alloy
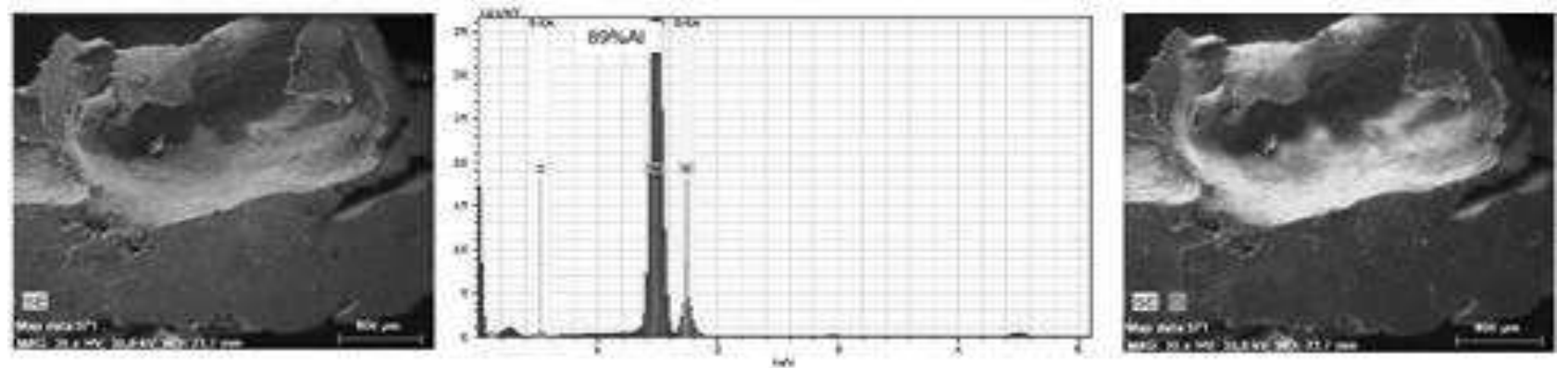

Fig. 3 Results of chemical microanalysis EDX medium sample AlSi12

Tab. 2 Weights of foamed samples from AlSi12 and their statistical evaluation

\begin{tabular}{|c|c|c|c|c|c|c|c|}
\hline \multicolumn{8}{|c|}{ Statistical evaluation of the weight of foamed samples from AlSi12 alloy } \\
\hline \multicolumn{5}{|c|}{ Weights of samples $[\mathrm{g}]$} & Average $\overline{\mathbf{X}}[\mathrm{g}]$ & $\begin{array}{l}\text { Standard devi- } \\
\text { ation }\end{array}$ & $\begin{array}{l}\text { Coefficient of var- } \\
\text { iation }\end{array}$ \\
\hline 15.19 & 15.77 & 16.02 & 15.96 & 16.15 & 15.82 & $3.77 \cdot 10^{-1}$ & $2.38 \cdot 10^{-2}$ \\
\hline
\end{tabular}

Based on the produced samples from aluminium alloy AlSi12 (see Fig. 3), their weights were determined and statistically evaluated - see Tab. 2.

By the equations of authors' $[1,14,15]$, were calculated the following values of foamed parts from aluminium alloy AlSi12. Important findings about aluminium alloys have been taken from $[16,17]$. To evaluate the properties of the produced aluminium foam, the following quantities were determined: density, porosity, volume fraction of solid phase, Young's modulus and strength of foamed samples.

\subsection{Determination the density of produced alumin- ium foam from AlSi12 alloy}

Density determination can be performed by the physical calculation according to the known relationship:

$$
\rho_{\mathrm{Al}_{\_} \mathbf{F}}=\frac{\mathbf{m}_{\mathrm{Al} \_\mathrm{F}}}{\mathbf{v}_{\mathrm{Al}_{\mathbf{F}} \mathrm{F}}}\left[\mathbf{k g} \cdot \mathbf{m}^{-3}\right]
$$

Where: $\mathrm{m}_{A l_{-} F}$ - weight of foamed aluminium alloy $[\mathrm{kg}] ; \mathrm{V}_{A l_{-} F}-$ volume of foamed aluminium alloy.

By substituting into equation (6), the density of the foamed aluminium alloy samples can be determined (see Tab. 3). 


\subsection{Determination of the AISi12 alloy foam relative} density

$$
\rho_{\mathrm{REL}}=\frac{\rho_{\mathrm{AlI}}}{\rho_{\mathrm{BM}}}[\mathbf{1}],
$$

Where: $\rho_{\text {AIF }}$ is the density of the metal foam sample $\left[\mathrm{kg} \cdot \mathrm{m}^{-3}\right] ; \rho_{\mathrm{BM}}$ is sample density of the relevant alloy without foaming $\left[\mathrm{kg} \cdot \mathrm{m}^{-3}\right]$.

AlSi12 alloy density is $2660\left[\mathrm{~kg} \cdot \mathrm{m}^{-3}\right]$. After substitution into equation (7), the value of $1.59 \cdot 10^{-1}$ can be calculated (see Table 3).

\subsection{Determination of foamed aluminium alloy AISi12} porosity

$$
\mathbf{P}=\frac{\rho_{\mathrm{BM}}-\rho_{\mathrm{Al} F \mathrm{~F}}}{\rho_{\mathrm{BM}}} \cdot 100[\%],
$$

By substituting into Equation (8), the porosity value of the foamed aluminium alloy samples can be determined (see Table 3).

\subsection{Determination of the AISi12 alloy foam Yong's} modulus

$$
\mathbf{E}_{\mathrm{Al} \_\mathrm{F}}=\mathbf{k} \cdot \mathbf{E}_{\mathrm{BM}} \cdot\left[\mathbf{0 , 5} \cdot\left(\frac{\rho_{\mathrm{Al} F}}{\rho_{\mathrm{BM}}}\right)^{\mathrm{m}}+\mathbf{0 , 3} \cdot\left(\frac{\rho_{\mathrm{Al} F}}{\rho_{\mathrm{BM}}}\right)^{\mathrm{m}}\right]
$$

Where: $\mathrm{E}_{\mathrm{M} . \mathrm{F}}$ is Young's modulus of foamed system [MPa], $\mathrm{E}_{\mathrm{BM}}$ is Young's modulus of foamed material $[\mathrm{MPa}] ; \rho_{\mathrm{MF}}$ is sample density of the relevant alloy without foaming $\left[\mathrm{kg} \cdot \mathrm{m}^{-3}\right] ; \rho_{\mathrm{BM}}$ is sample density from foamed aluminium $\left[\mathrm{kg} \cdot \mathrm{m}^{-3}\right] ; \mathrm{m}$ is constant for calculation the Young's modulus $\mathrm{m}=2$ [14], $\mathrm{m}=1.5$ to 1.7 [15], $\mathrm{k}$ is constant for calculation the Young's modulus $\mathrm{k}=1$ [11]; $\mathrm{k}=(0,1$ to 4$),[15]$. To calculate Young's modulus, there was used $\mathrm{k}=0.1$ and $\mathrm{m}=2$.

By substituting the appropriate values in equation (9), the Young's modulus of the foamed aluminium alloy can be calculated (see Tab. 3).

Tab. 3 Calculated properties of the foamed aluminium alloy

\begin{tabular}{|l|c|c|}
\hline \multicolumn{1}{|c|}{ Determination the average values of properties measured for aluminium foam (AlSi12 foam) } \\
\hline \multicolumn{1}{|c|}{ Calculated properties } & Value & Units \\
\hline $\begin{array}{l}\text { Density of foamed aluminium alloy or density of its discretized structure }\left(\rho_{\mathrm{Al} \_}\right) \\
\text {(sample size } 150 \mathrm{~mm} \times 25 \mathrm{~mm} \times 10 \mathrm{~mm})\end{array}$ & 422 & {$\left[\mathrm{~kg} \cdot \mathrm{m}^{-3}\right]$} \\
\hline $\begin{array}{l}\text { Relative density of the foamed aluminium alloy }\left(\rho_{\mathrm{REL}}\right) \\
\text { (sample size } 150 \mathrm{~mm} \times 25 \mathrm{~mm} \times 10 \mathrm{~mm})\end{array}$ & $1.59 \cdot 10^{-1}$ & {$[1]$} \\
\hline $\begin{array}{l}\text { Porosity of foamed aluminium alloy }(\mathrm{P}) \\
\text { (sample size } 150 \mathrm{~mm} \times 25 \mathrm{~mm} \times 10 \mathrm{~mm})\end{array}$ & 84 & {$[\%]$} \\
\hline $\begin{array}{l}\text { Young's modulus of foamed aluminium alloy }\left(\mathrm{E}_{\mathrm{AlF}}\right) \\
\text { (sample size } 150 \mathrm{~mm} \times 25 \mathrm{~mm} \times 10 \mathrm{~mm})\end{array}$ & 148 & {$[\mathrm{MPa}]$} \\
\hline
\end{tabular}

\section{Conclusion}

As a result of research there is comparison of the theoretical calculations for density of the foamed AlSi12 material obtained by applying equations (2), (3), (4) and (5). Thus determined densities values were compared with the density of test samples (cuboid shape, $150 \mathrm{~mm} \times 25 \mathrm{~mm}$ x $10 \mathrm{~mm}$, powder metallurgy from AlSi12 alloy, with 0.6 wt. \%). Based upon these calculations, it was found that about $0.2 \mathrm{wt} \%$ of the $\mathrm{TiH}_{2}$ foaming agent is needed to achieve the AlSi12 alloy foam density equal to $422 \mathrm{~kg} \cdot \mathrm{m}^{-}$ 3 . For the production of aluminium foam by the powder metallurgy method is used $\mathrm{TiH} 2$ foaming agent of 0.6 to $1 \mathrm{wt} \%$. A significant difference in the determined density of produced AlSi12 aluminium alloy by the chemical calculation according to equation (2) and density determined for produced AlSi12 aluminium alloy can be seen in other factors that are necessary for the production of foam namely the use of a certain amount of $\mathrm{SiC}$ as stabilizing agent or other ceramic materials. The $\mathrm{TiH}_{2}$ foaming agent used in the foaming process requires careful attention as well as a lot of theoretical knowledge and practical experience. The choice of an unsuitable technological foaming process can lead to initiation of cracks and cracking of aluminium foam walls.

Our research also suggests that the production of foamed aluminium or aluminium alloy samples is very demanding and requires a variety of knowledge from chemistry, physical chemistry and physical metallurgy. It also requires knowledge of the physical-chemical behaviour of foaming and stabilizing agents and the metallurgical behaviour of aluminium alloys to these agents. Produced foam samples $(1500 \mathrm{~mm}$ x $25 \mathrm{mx} 10 \mathrm{~mm})$ from AlSi12 alloy were subsequently analysed with the following basic results: density $422 \mathrm{~kg} \cdot \mathrm{m}^{-3}$, relative density $1.59 \cdot 10^{-1}\left(1.59 \cdot 10^{-1}\right.$ x $\left.2660=422 \mathrm{~kg} \cdot \mathrm{m}^{-3}\right)$ and Young's modulus $148 \mathrm{MPa}$.

\section{Acknowledgement}

The work has been financially supported by the project "Hybrid materials for hierarchical structures", research goal: Composite materials and structures, research program: Materials and structures on the metal basis, reg. no. CZ.02.1./0.0/0.0/16_019/0000843 provided by the European Union and the Czech government. 


\section{References}

[1] ASHBY, M.F. EVANS, A. FLECK, N.A. GIBSON, L.J. HUTCHINSON, J.W and H.N.G. WADLEY. (2000) Metal foams - a design guide. Butterworth-Heinemann, London

[2] BANHART, J. (2001) Manufacture, characterisation and application of cellular metals and metal foams. Progress in Material Science, 46, pp.559632.

[3] BANHART, J, (2013) Light-Metal-Foams -History of Innovation and Technological Challenges. Advanced Engineering Materials, 15, No 3, pp. 82-111.

[4] RAJAK, D.K. KUMARASWAMIDHAS, L.A. and S.DAS. (2017) Technical Overview of Aluminium Alloy Foam. Reviews on Advanced Materials Science 48, pp. 68-86.

[5] THIES, M. (2005) Lattice Boltzmann Modelling with Free Surfaces Applied to Formation of Metal Foams. [Doctoral thesis]. Technical University Erlangen - Nürnberg in Erlangen, German.

[6] MATIJASEVIC, B. BANHART, J. FIECHTER, S. GÖRKE, O. and N. WANDERKA (2011) Modification of titanium hydride for improved aluminium foam manufacture. Preprint submitted to Elsevier Science, 5 Marc,. pp.1-35.

[7] KRESSE, R. (1999). Characteristics and handling of titanium hydride. In. Banhart, J., Ashby, M. F. and Fleck, N. A., editors, Metal Foams and Porous Metal Structures, MIT Publishing, Bremen, pp. 109-112.

[8] YANG, D. and B. HUR. (2006) The relationship between thermal decomposition process of titanium hydride and the Al ally melt foaming process. Materials Letters 60, pp, 3635-3641.

[9] SIMMONS, J. A. SPRITTLES, J.E. SHIKHMURZAEV. Y. D. (2015) The formation of a bubble froma submerged orifice. Preprint submitted to European Journal of Mechanics B/Fluids, February 24, pp. 1- 4.

[10] SAN-MARTIN A, MANCHESTER F. D. (1987) The H-Ti (hydrogen titanium) system. Bulletin Alloy Phase Diagram, 8 pp. 30-42.

[11] ZEPPELIN, F. V., HIRSCHER, M., STANZICK, H., and J. BANHART, (2003). Desorption of hydroge from blowing agents used for foaming metals. Composites Science and Technology, 63, pp. 2293-2300.

[12] ORT, M. (2008) The Utilization of metal foam in automotive industry parts. [Diploma thesis]. Faculty of Engineering. Technical University of Liberec.

[13] JERZ, J. Foamed Aluminium and Aluminium Alloys Prepared by Powder Metallurgy, Ph.D. Thesis, TU Vienna, 1995.

[14] MORENO, F.G. (2016) Commercial Application of metal Foams: Their properties and production. Materials, 9. 85, pp. $1-27$.

[15] SURACE, A. R. DE FILIPPISB, L. A. C. LUDOVICOA, A.D. and G. BOGHETICHC (2007) Experimental analysis of the effect of control factors on aluminium foam produced by powder metallurgy. Proceeding. Estonian Academy. Science Engineering, 13, 2, pp. 156-167.

[16] MICHNA, Š., HREN, I., SVOBODOVÁ, J. (2019) The Research of the Effect of High Fe Content on AlSi9NiCuMg0.5 Alloy. Manufacturing Technology. Vol. 19, No. 1, pp. 107-113. ISSN 1213-2489.

[17] SOBOTKA, J., SOLFRONK, P., KOLNEROVÁ, M., KOREČEK, D. (2017) Fatigue Properties of the Aluminium Alloy AW-5182 in dependence on Deformation Manufacturing Technology. Vol. 17, No. 6, pp. 958-962. ISSN 1213-2489. 